\title{
Nominalism and History
}

\author{
Cody Franchetti \\ Graduate School of Arts and Sciences, Columbia University, New York, USA \\ Email: history@codyfranchetti.com
}

Received March 23 $3^{\text {rd }}, 2013$; revised April 23 $3^{\text {rd }}, 2013$; accepted May $1^{\text {st }}, 2013$

Copyright (C) 2013 Cody Franchetti. This is an open access article distributed under the Creative Commons Attribution License, which permits unrestricted use, distribution, and reproduction in any medium, provided the original work is properly cited.

\begin{abstract}
The paper focuses on Nominalism in history, its application, and its historiographical implications. By engaging with recent scholarship as well as classic works, a survey of Nominalism's role in the discipline of history is made; such examination is timely, since it has been done but scantily in a purely historical context. In the light of recent theoretical works, which often display aporias over the nature and method of historical enquiry, the paper offers new considerations on historical theory, which in the author's view may solve some of the contradictions that have surfaced in recent times. The Nominalistic stance is argued against by disputing theorists such as Paul Veyne, who has made a case for Nominalism in history. A brief philosophical section introduces Nominalism in its metaphysical dimension and the discussion is speedily brought to its significance for history. The paper also proposes a solution to the misconstrued yet too often vague application of scientism in history, and offers theoretical grounds that might solve some of the 'stormy grounds' historiography finds itself today. Articles by Marcel Gauchet and History and Theory's Anton Froeyman and Bert Leuridan are engaged with, as well as Murray Murphy's books on the philosophy of history. Works by Georg Gadamer, Marc Bloch, Benedetto Croce, Hyppolite Taine, and Anthony Grafton crucially inform the discussion and brace the consequential conclusion.
\end{abstract}

Keywords: Nominalism; Particulars \& Universals in History; Nomothetic History; Empiricism; Hermeneutics; History as Humanity vs Science; Historical Narrative

\section{Introduction}

The role of Nominalism in history has been seldom discussed, seldom considered, and even more seldom analyzed. Surely if asked, any historian would tender an opinion on the Nominalist/Realist antithesis, and favor one persuasion over the other as it relates their convictions about what is sound historical methodology. But most, I venture to say, would recognize that they have not given deep thought about how this crucial philosophical argument applies to their historical thinking. The dispute between Realists and Nominalists has raged in metaphysics for over two millennia - and is still the source of animated debates-but in historical circles the argument, save a few instances, has not been confronted directly on its own, diametrical terms. The aim of this essay is to present the reader with an assessment of the role of Nominalism in history, which, as far as I know, has not yet been wholly laid out for an outright historical readership. Although I shall present the various pertinent sources and their theories in order for readers to form an opinion of their own, I should like to point out that this essay's objective is to discredit the idea that strict Nominalism alone be an apposite stance in conceiving history. Still, I believe particulars to be the cornerstone for historical understanding; and yet, I am also convinced that historians who ignore universals and exclusively scrutinize particulars will find their work wanting of characteristics, which if overlooked, shall fatally compromise their historical apprehension. In other words, I wish to show that though particulars have a vital place in history-and we shall see why-Nominalism is epistemologically deficient, especially in history, for universals are an inalienable aspect of human understanding, and thus are essential for a thorough conception of history and a comprehensive historical grasp: history's singularly extensive compass requires a broad vision that accepts both universals and particulars.

Robert Hume appositely stated that, "[t]he philosophy of history has long been a stormy ground, and it will probably remain so." (Hume, 1999: p. 13) In fact, philosophers of history are continuously examining and arguing over the ontology of history; its fractious, hybrid nature is ultimately an endless source of speculation and fervid discussion. The main point of contention - which is also fundamental for our analysis - seems to me the question of whether history is a science or a humanistic pursuit, and, if it is the latter, how and in what way does it differ from other humanistic disciplines, due to its para-scientific slant. While it is not the task of this essay-providentially - to enter this acerbic dispute, our study of Nominalism and history must necessarily include a discussion of history as science and history as a humanity, because those who favor the Nominalistic stance tend toward the persuasion of history as a form of empirical knowledge, and thus view it through scientific lenses; on the other hand, Realists envision history as a discipline under the aegis of the humanities, whose epistemic tools are hermeneutics rather than Method. ${ }^{1}$

I will show that despite the quagmire of opinions, currents, and theories, whether one regards history as a science or as a

${ }^{1}$ As has been shown by Gadamer in Truth and Method. Gadamer, however, did not write about Nominalism at all. 
humanistic pursuit strict Nominalism is fatally reductive to either conviction: it is in serious philosophical tension with the former and irreconcilable with the latter.

Since Nominalism and Realism's connection to history can best be judged with a clear understanding of their more abstract, philosophical perspective, I will first present the Nominalist/Realist antithesis in its purely philosophical dimension; this should provide the necessary understanding when the argument is applied to history. Next, I will cover the few, meaningful sources that pertain to our discussion; these shall be from different philosophies of history, which examine the question on a purely historiographical basis. I have already stated that the sources dealing directly with Nominalism and history are scanty: philosophers of history who labor either for the scientific or the humanistic view often do not confront Nominalism and Realism directly, and thus some degree of inference shall be required to locate their stance from their arguments. ${ }^{2}$ I will then cover the most heated and productive dispute - that between Paul Veyne and Marcel Gauchet, over the legitimacy of historical Nominalism - which is the only modern debate directly centered on the philosophical and historiographical positions we are examining. Lastly, I will both attempt to present what seems to me the most sensible solution to the tendentious, Nominalist/Realist polemic and provide a sound argument against these unnecessarily polarized tenets and their role in history. I hope to provide at the very least, a certain degree of mental order - of food for thought - rarely furnished to the practicing historian, on the relation of Nominalism and history.

\section{A Brief Philosophical Preparation}

It is a well-known fact that the first to posit the theory of universals was Plato. This epistemological theory is of cardinal importance: it has engaged metaphysical speculation since its inception; its claims have been as fecund as any great question in philosophy. In fact, whether we know the world through its intelligible manifestations, through direct perception, or, whether we only really know the world through Forms, the unintelligible, is really the marrow of epistemology. Throughout his dialogues, Plato continuously alludes to what he refers to as "Forms". The Republic is the classic, most quoted example: "shall we proceed as usual and begin by assuming the existence of a single nature or Form for every set of things which we call by the same name?" (Plato, 1961: p. 820) These words, pronounced by Socrates in the dialogue, are as ambiguous as they are famous. David Armstrong, who has devoted the most comprehensive modern survey of Nominalism and Realism in his two-volume work, Universals \& Scientific Realism, points out the ambiguity of this passage: "But is Plato here arguing that the Form is required for the name to be meaningful? That is the way in which he is often interpreted. However, it is at least as plausible to suggest that the underlying argument is that sameness of name requires sameness of nature in the things named." (Armstrong, 1978: Vol. 1, p. 98) Despite the ambiguity of the act of naming things ${ }^{3}$ in the statement quoted from Republic-whether sameness of name requires sameness of nature in

\footnotetext{
${ }^{2}$ Such inferences shall not unmotivated and neither discretionary nor arbitrary.

${ }^{3}$ Plato dedicated his Cratylus to discussing the implications of naming things (especially at the end of the dialogue from sections 438 to 440), man as a name-giving creature, and language's relationship to truth.
}

the things named or whether Forms are a prerequisite for the ability to name things - particulars are understood by Plato to be a subset of Forms ("the existence of a single nature or Form for every set of things which we call by the same name"). In Parmenides, Plato is more specific in detailing the discrete existence of Forms: "Do you believe that there is such a thing as likeness itself apart from the likeness that we possess? Certainly I do, said Socrates." (Plato, 1961: p. 924) Here Plato is positing that universals and particulars exist as separate entities.

The Platonic theory of Forms is very complex due to the allusive, almost epigrammatic way which Plato scatters his dialogues with his references to them; Plato's idea of universals is open to a number of interpretations, which may lead to rather different conclusions. It is not our concern here to examine the theory of universals in all its metaphysical ramifications, but to lay the basic philosophical principles which will be engaged when discussing Nominalism and Realism and their role in historical perception; the reader must merely be made aware of the choices offered by this vital epistemological dilemma: does our knowledge stem exclusively through our direct perception of particulars or as an emanation of Forms? Do we accept or reject the existence of universals? This is the question which has fomented endless discussion-and in some cases derision: Wittgenstein famously claimed this problem to be a non-issue.

But let us now define with as much clarity as possible what Nominalists and Realists believe. I shall call upon David Armstrong's definition for both terms:

There are those philosophers who hold that when we say truly that two tokens are of the same type, then sameness is to be understood in terms of strict identity. The two different tokens have something strictly identical. [...] If, for instance, two different things have the same color, then this must be taken strictly. One and the same thing, the color, is a constituent of the two things. Historically, these philosophers are called Realists and are said to believe in the reality of universals.

On the other side there are philosophers who think that when we say that a number of tokens are all of the same type, then all that we are saying is that the different tokens are non-overlapping parts of some larger whole or unity (the tokens are all member of one class, or they all resemble each other in a certain way, or some other such formula). The sameness of the tokens is only loose and popular.

These philosophers hold with John Locke, that "all things that exist are only particulars". There are no strict identities reaching across different tokens; there are no universals. Philosophers who hold such a view are traditionally called Nominalists. (Armstrong, 1989: p. 5)

In other words, Nominalism is the rejection of universals, while Realism is the belief in their existence. There are various forms of Nominalism - Concept Nominalism, Class Nominalism, Resemblance Nominalism, which all fall under the socalled heading of Predicate Nominalism-as well as various kinds of Realism: Immanent Realism and Scientific Realism. These distinctions are immaterial to our discussion and I shall relegate them to broader, strictly metaphysical discussions. It is now time to speak of the concepts outlined above in relation to history and see how they affect our conceiving history. 


\section{FRANCHETTI}

\section{Particulars and History}

The first to proclaim that historians dealt above all with particulars, or "singulars", as he referred to them, was Aristotle. In Poetics Aristotle distinguished the historian from the poet as follows:

The distinction between historian and poet is not in the one writing prose and the other verse-you might put the work of Herodotus into verse, and it would still be a species of history; it consists really in this, that the one describes the thing that has been, and the other a kind of thing that might be. Hence poetry is something more philosophic and of graver import than history, since its statements are of the nature rather of universals; the statements of history are singulars. (Aristotle, 1946: p. 1451b)

Aristotle thus inaugurated the Nominalist viewpoint in the discipline of history. This persuasion had enough thrust to persevere until today and has been the source of many fruitful debates in historiography, though most debates are not always conscious of the Nominalism/Realism antithesis at their root nor its implications when applied to the discipline of history; furthermore, the friction between universals and particulars is aggravated, when, as historians, we apply the indefeasible element of our discipline - temporality - in our consideration. For example, when we say that, "a certain person whom we saw today is the very same person that we saw yesterday [...] does that mean that the person today and the person yesterday are actually identical?" (Armstrong, 1989: p. 3) Thus we can see how temporality complicates particulars and their perception, for we can say with some confidence that the person yesterday is the same as the person today. But only loosely. Strictly speaking, "they are different temporal parts of a single fourdimensional entity, the person." (Armstrong, 1989: p. 4) This ties itself to a principle - controversial in philosophy - called the Identity of Indiscernibles, which holds that "if a and b have all their properties in common, then a is identical with $b$. In other words, sameness of properties gives sameness of thing." (Armstrong, 1989: p. 3) Universals, too, are affected by this principle, for in order to recognize them-just as we do particulars - we must apply the principle of Identity of Indiscernibles. In history, this involves the recognition of sameness through time for universals - if we believe in them, of course. But since history is the study of the change of human practices, particulars clearly bear greater significance for the historian, for it is by analyzing particulars that we can readily recognize change: temporality makes particulars dependent on their temporary instant, and therefore significant inasmuch as they reveal the historical moment we are examining. On the other hand, in the animated debate between Paul Veyne and Marcel Gauchet, we shall see that universals are not to be discounted. The dispute was centered on particulars-how, why, and to what extent they are meaningful in historical inquiry. In examining their claims, I think what should transpire is that particulars alone and the refutation of universals - Nominalism - severely limits the historian's gaze.

\section{Paul Veyne and the Chimera of the Nominalist Historian}

Paul Veyne is the modern historian who wrote explicitly about Nominalism and history, and who argued for a Nominal- ist outlook. He wrote about it in his theoretical writings on history. His first book, Writing History, is full of driving ideas about historical methodology as well as fruitful considerations about the ways a historian crafts his work. Though throughout the book Veyne offers a number of stimulating insights, he often stumbles in contradictions that mar the coherence of his thought: Veyne's view of history is staunchly Nominalist, yet his statements are often incongruous with the implications of Nominalism. Very early he states that, "nothing is more reasonable than a Nominalist conception of history" (Veyne, 1984: p. 43) and explains the legitimacy of this position by stating that "we know historical types do not exist in themselves, that events are not reproduced with the constancy of living species, that the typical in history is a choice [...] in short, the types are infinite in number, since they exist only through us. Once again, we have to come to the conclusion of historical Nominalism." (Veyne, 1984: p. 121) Veyne's argument is essentially that the historian ought to look to particulars and reject universals - which here he calls "historical types"- since only the former can reveal the historical moment in its uniqueness, thus implying that the belief in universals hampers a historian's understanding. In his most well known essay, Foucault Revolutionizes History, Veyne further expanded this idea:

In short, in any given era the set of practices gives rise, on a given material point, to a unique historical countenance in which we think we recognize what is called, in vague terms, historical science or religion; but what takes shape at that same point in another era will have its own unique and very different countenance and, conversely, a countenance vaguely similar to the earlier one will take shape at a some other point. This is what denying the existence of natural objects means: across the ages we do not encounter the evolution or modification of a single object that always appears in the same place. (Veyne, 1997: p. 171)

Again, Veyne makes a powerful and convincing case for the uniqueness of any historical moment, but he is less persuasive when he argues that across the ages we never encounter the same things. A few pages later, Veyne drives this point further: "there is no concrete trans-historical truth." (Veyne, 1997: p. 174)

Marcel Gauchet fulminated Veyne for his extreme Nominalist position. In an article called Le nominalisme historien. A propos de "Foucault révolutionne l'histoire" de Paul Veyne, Gauchet faulted Veyne for the stringent Nominalism he displayed in his essay on Foucault, and claimed Veyne's ideas to be the result of a naïve skepticism "scepticisme naiff" (Gauchet, 1984: p. 409), reminiscent of a second-degree scientism that could never allow authentic historicity. For Gauchet, the Nominalist epistemology is a "nullifying" philosophy: "[with his] strange epistemology, no time is seriously considered by Veyne to historical conditions of formation of this knowledge of historical fact according to standards of accuracy. This generalized genealogy excludes but one genealogy: its own. In other words, everything is historical, except history." (Gauchet, 1986: p. 407) ${ }^{4}$ Furthermore, according to Gauchet, Veyne is ignorant of the foundations of historical methodology. He refers

${ }^{4}$ Or, étrange épistémologie, à aucun moment il n'est sérieusement réfléch chez Veyne aux conditions historiques de constitution de cette connaissance du fait historique selon des normes d'exactitude. Cette vision généalogique généralisée n'exclut qu'une généalogie: la sienne propre. Tout est hiostorique, en somme, sauf l'histoire. 
to Veyne's “authentic misunderstanding" citing Veyne's claim that historians of antiquity and the Middle Ages were a-critical, because they built their histories upon their predecessors'. According to Gauchet, this view is summary and erroneous, since Gauchet points out that historians before historicism were indeed critical $^{5}$ but were so with completely different criteria from our own. For Gauchet, Veyne's ignorance creates a fatal blind spot in Veyne's historical epistemology; it is that spot, which accounts for the Nominalist's fortune.

The main task which an authentic epistemology of today must provide: dissolve the sophisms that naturally result in this renewed version of universal mobility. The fact that everything is historical does not mean that everything is relative, that history is made of nothing but radical heterogeneities and woven by singular, incomparable emergences. But it is precisely this challenge, that all is historical, that must be met. What does it mean, exactly? That death, tears, childhood, dreams, sexuality, folly are historical in their essence and not like natural objects always identical with themselves; but what does that truly mean? Since there is uncertainty about this point, skepticcism and historical Nominalism arise and thrive. (Gauchet, 1986: p. 406) ${ }^{6}$

However Gauchet did explain particulars' own, rightful place in conceiving history, and wrote about it exemplarily: "History [is] the emergence, the advent of forms than cannot be explained, except by missing what matters in them, that is, what these forms have that is incomparable. From this comes the necessity of the historian's Nominalism, the only position that can adequately open him to the inexplicable singularities of a process of permanent innovation." (Gauchet, 1986: p. 403) ${ }^{7}$

Paying close attention to particulars to make the historian "open to the singularities" of a period is a process which we shall examine in its metaphysical dimension; but after Gauchet's sensible statement we have established particulars' exigency and that universals alone are insufficient for conceiving history. For example, if we consider the idea of "the State" we surely cannot find much in common among the Roman State in the first century AD, the State under Louis XIV, and, say, the bureaucratic Napoleonic State. ${ }^{8}$ Clearly, if we were to look exclusively through the lens of forms we'd make historically insignificant statements. (However, further on I shall present a more sophisticated concept of universals that discounts Nominalism in every epistemological maneuver.)

\footnotetext{
${ }^{5} \mathrm{He}$ is quite right in saying so: see Nadel, 1964.

${ }^{6}[\ldots]$ la tâche prioritaire que doit se proposer une authentique épistémologie historique ajourd'hui: dissoudre les sophismes qui paraissent naturellement découler de cette version renouvelée de l'universelle mobilité. Le fait que tout est historique ne signifie aucunement que tout est relatif, que l'histoire n'est fait que d'hétérogénéités radicals et tissé que des surgissements incomparables. Mais c'est très précisément à ce défi du tout est historique qu'il s'agit de répondre. Qu'est-ce au juste que cela veut dire? Que la mort, les larmes, l'enfance, la rêve, la sexualité, la folie soient d'essence historique et non pas autant d'objets naturels toujours identiques à eux-mêmes, qu'est-ce que cela véritablement signifie? Car c'est de l'incertitude sur ce point que naissent et prospérent le scepticisme et le nominalisme historiques.

${ }^{7}$ L'histoire qui est le surgissement, l'avénement de formes qui ne saurient s'expliquer, sauf à manquer ce qui compte en elles, à savoir ce que'elles comportent d'incomparable. D'où le nécessaire nominalisme de l'historien, seul à meme de l'ouvrir adéquatement aux singularités inexplicables d'un processus d'innovation permanente.

${ }^{8}$ The example is Gauchet's.
}

Gauchet thus expounded brilliantly on the need to concentrate on particulars in historical enquiry. But the benefits of a composed Nominalism in conceiving history surely are not new: "Herder set a universal historical worldview against the Enlightenment's teleological view of history [...] to acknowledge that each period has its own right to exist, in its own perfection." (Gadamer, 2004: p. 198) I think it should now be evident that particulars do have a fundamental role in our understanding of a historical moment.

And yet, as Fustel de Coulanges said, "History is not the accumulation of facts and events of every sort that have been produced in the past: it is the science of human societies" (Bloch, 2005: p. 71$)^{9}$ and as such, one must be aware that, as we saw above, contrary to Veyne's stating the contrary, "transhistorical truths" exist, because there are constants in human nature - vanity, rapacity, the wish for a better position in society, love, lust, etc. And the historian who disregards timeless human traits inevitably shall not set them against the period he is studying - which is of course exemplary and unrepeatable - thus finding his compass of vision considerably diminished by such heedlessness. Furthermore, Veyne's negation of trans-historical truths presents another, perhaps greater problem, especially for historians: a generation inherits certain beliefs and practices from a previous one; as that transference occurs, these beliefs and practices gradually change. By denying these constants the effects of temporality on man are ignored. That is nonsensical for an historian, whose charge is to be a most sensitive needle on the scale of change over time.

Let us remember Dilthey's precept that "we can explain things but we understand men". This important distinction shoulders us to what is probably the most insightful quote from Marc Bloch's The Historian's Craft, that undisputed masterpiece of twentieth-century historical methodology: "If men, who are the object of our study, fail to understand us, how can we feel that we have accomplished more than half our mission?" (Bloch, 1953: p. 86-87) Therefore, if we be understanding of men, how could we discount universals, which inexorably constitute his nature? And furthermore, the rightful insistence that these two great historians placed on understanding over explanation is really a charge that explanation in history has scientific inclinations, either by virtue of an unobtainable law-covering model, or by impossible empiricism for the causal explanations of events. And so, a crucial aporia rises before us here: a choice must be made between hermeneutic and scientific knowledge, for a hermeneut cannot be an empiricist. This was demonstrated most powerfully by Gadamer in Truth and Method: Gadamer revealed hermeneutics to be an ulterior form of knowledge bearing truth outside Method - the indefeasible foundation of natural science.

With this in mind, Veyne's contradictions begin to emerge, and they reveal to be problematic. Two contradictions in Veyne's Writing History, which diminish the efficacy of his theory considerably, are most pertinent to our discussion. The first is his statement that " $\mathrm{t}]$ he historical explanation is not nomologic, it is causal; as causal, it contains something general". Is Veyne flirting here with Realism ("it contains something general") and contradicting his purported Nominalism

\footnotetext{
${ }^{9}$ La storia non è l'accumulazione degli avvenimenti d'ogni tipo che si sono prodotti nel passato: essa è la scienza delle società umane.

Marc Bloch cited de Coulages's affirmation in his last, scattered papers on history, written just before being shot in 1944 by the Gestapo.
} 
with the irruption of universals in historical explanation? Secondly, Veyne, argues that "history is not a science." (Veyne, 1884: p. 144) But Veyne, in his essay on Foucault, praised him for his empiricism - for statements such as, "history becomes an empirical science of events and that radical mode of being that prescribes their destiny to all empirical beings, to those particular beings that we are" (Foucault, 1994: p. 219)—which according to Veyne made Foucault a better kind of historian. We have already seen the ontological tension that arises from these two positions standing side by side, for it is impossible for them to be bridged in any way.

Even in his most defensible apology for Nominalism Veyne finds himself hampered by this single-handed theoretical concern: "[...] historical Nominalism, the vague character of sublunary causality, makes it that no order of causes constantly imposes itself as more decisive than the others." (Veyne, 1984: p. 280) I think Veyne's insistence on Nominalism, is the manifestation of a natural and widespread fear among historians - the fear of being faulted for not being sufficiently analytical. But analytical acumen is but one ingredient that makes a great historian. And so, Gauchet's charge of Veyne's relative ignorance of historical methodology seems correct to me: Veyne's statement above, which upon its first reading seems sound, is really only valid for attempts at causal explanations of historical events, but it is utterly useless for broader notions of history, which as I suggested above, must also understand man, and, gauge with great accuracy the change in human practices. It is worthwhile here to remember Vico's celebrated dictum that history "discloses the realm of culture, not nature": and so, the historian who handles culture must take into account human temperament, and the latter-it should be stressed again- has universals and forms that ought not to be dismissed. In addition, Vico's statement is an excellent refutation-on its own-for using natural science's practices (contra Veyne and his empirical stance).

Despite my quibbles with Veyne's theoretical writing, I should like to point out that when he actually writes history, Veyne is a great historian, and practices history in the most integral fashion. But in his theoretical writings there is an underlying philosophical uneasiness, which stands in the way of his speculations. However, this should not diminish Veyne's accomplishments in our eyes, since often people do something very well even if the theory they use to explain what they do is flawed.

\section{Nominalism's Attempts at a View of History Conforming to Scientific Knowledge}

An interesting yet defective attempt for a philosophy of history analogous to science and that brims with sharp Nominalistic positions is offered by Murray Murphy. In his book, Philosophical Foundations of Historical Knowledge, Murphy seeks rather hopelessly to reconcile the theories of historical causal explanation put forth by Carl Hempel and Paul Oppenheim in their Deductive-Nomological model for scientific explanation -with which they sought to explain any given historical event with a series of "logically deductive premises" (Murphy, 1994: p. 98) - and the concept of "culture", which according to Murphy must also be considered as an explanation for human actions. Murphy casts eight propositions about historical knowledge, which he believes to be verifiable; the last is also the thorniest, for it states that "human actions are causally explain- able." (Murphy, 1994: p. x)

For human actions to be causally explainable, Murphy upholds to the so-called "covering law":

This [...] model of explanation [is] from the metaphorical idea that the general law "covers" the particular case. It involves certain presuppositions that should be noted. One is that all laws are general, that is, the law cannot contain any reference to a particular. This was seen as necessary to rule out "general" statements such as "All chairs in this room are made of wood". For the same reason, Hempel and Oppenheim stipulated that laws could contain only purely qualitative properties, so that properties referring to particulars (e.g., "earthly”) are proscribed. (Murphy, 1994: p. 98)

At first this may seem to be a Realist position, since laws evince some form of 'generality' and are meant to be universal. But Nominalists hold that only physical particulars in space and time exist, and that universals, which do not, are at best subsequent to particular things; therefore general laws are brought into being by particulars, and, in the case of history, laws would provide predictability, which of course is unfeasible. Robert Hume, who, in his excellent book, Reconstructing Contexts: The Aims and Principles of Archaeo-Historicism labels himself an empiricist, attacks Murphy's view by saying, "I think Murphy is overstating his case. To say that human action has causes is one thing; to say that we can identify them is something else" (Hume, 1999: p. 15). The last clause is apodictic: it is disarmingly obvious that every historian who has attempted to predict the future by using causal explanations for past events to forge laws for events, such as, say, revolutions, has always failed. Obviously, the covering law refutes universals categorically and places Murphy firmly in the Nominalist camp; Murphy accepts the covering law as an explanation for causality of events as well as action in history: "I believe there is no real doubt that the covering law model provides an explanation for an action [...]" (Murphy, 1994: p. 155). Hume expounds on the reasons for the mania of giving history a scientific footing to give it epistemological certainty as well as the deriving distortions of such attempts brilliantly.

Historians have long suffered from a dangerous hankering to be as precise and rigorous as physicists, and more than half a century ago history took a terrible turn when Hempel published "The Function of General Laws in History". Historians spent the next thirty years trying to get out from under the demands that follow from Hempel's attempt to impose on history the logical structure of explanation he found in physics. The gist of the "covering law model" is simplicity itself: explanation can be achieved "by subsuming what is to be explained under a general law".

In the cold aftermath of repentance at leisure, this is manifestly a lunatic idea. If history has general "laws", they are not of the sort to be found in classical physics. Physical science attempts to deal with something more or less available in the present; history attempts to explain the past now unrecapturable except via extrapolation from traces. The degree to which billiard balls can be used to explain human behaviour is evidently limited. More than a century ago Dilthey rightly distinguished between physical science (concerned with causal explanation of present 
phenomena) and history (concerned with comprehension of a vanished past). (Hume, 1999: pp. 15-16)

That a self-proclaimed empiricist like Robert Hume states unequivocally the fatal pitfalls of scientism applied to history is significant; and lunacy is indeed what incites a statement by Michael Scriven, which Murphy quotes in defense of his eighth proposition, which as we saw above states that "human actions are causally explainable", and which Scriven drives to its paroxistic locus: "causality is the most important explanatory function in history." (Murphy, 1994: p. 102) Now I should like to know which historian, in Scriven's or Murphy's view, has fully explained the cause(s) of, say, the French Revolution, which is about the most written event in history. Can an arsenal of "scientists" redact a nomological system for the Revolution? Compared to these desiccated attempts, Hyppolite Taine's overemphasized and infinitely figurative concept of "l'esprit classique" is indeed a tonic - for the comprehension of the spirit which animated the Revolution:

[Taine's] thesis is that the philosophy of the eighteenth century was the product of the "classic spirit", which was invented by Descartes and the essence of which was to pursue the absolute, and worship uniformity. When the French mind turned to politics it proceeded to prescribe according to the dictates of pure reason. This neglect of the individual, the concrete, the real, was the mark alike in literature, of the Philosophes and of the Revolution, and its predominance was the main cause of the tragedies of modern France. (Gooch, 1952: p. 228) ${ }^{10}$

Taine, like most historians of the nineteenth century, believed that history had both scientific and literary claims, which lent his history to a number of critical approaches. In his great work, Les Origines de la France Contemporaine, Taine had mastered the lessons of the august German school of history of the nineteenth century - that great efflorescence, which had produced unparalleled works written by men who engaged in the rigorous praxis of basing their histories on primary sources, as well as the necessity of understanding the reasons behind the actions of men. Accordingly, Taine employed a monumental archival knowledge with an almost unique, insightful psychological understanding; his great work is thus at the same time political philosophy, psychological history, social ethics, and, owing to its unique literary focus, literary criticism as well. For Taine, history was both an art and a science; his concept of the "esprit classique" sought - as Dilthey urged - also to comprehend, not just to explain. Bloch's reiteration of this is thus noteworthy: "This faculty of understanding the living is, in very truth, the master quality of the historian.” (Bloch, 1953: p. 43)

The rich idea of "l'esprit classique" opposes Veyne's much vaunted idea that Foucault's merit-and supposed superiority-was that he was both an empiricist and a profoundly skeptical thinker "who believed only in the truth of facts [...] never in the truth of ideas" (Veyne, 2010: p. 1) ${ }^{11}$ and that thanks to this supposedly sharpened, empiricist gaze, he managed to "peel away the banalities and notice that there is more to ex-

\footnotetext{
${ }^{10}$ For Taine's own, extensive presentation of "l'esprit classique", see Chapter 2 of Book 3 in: Taine, 1986.

${ }^{11}$ Here Veyne is projecting his thought onto Foucault's: in The Order of Things, Foucault evinces a clear regard for ideas and their veracity (See next footnote).
}

plain" (Veyne, 1997: p. 156) than what was previously understood about a period. But in arguing that Foucault revolutionized history Veyne forced the issue. ${ }^{12}$ Again, the example of the French Revolution stands before us: if we are to explain it through facts, such as, among others, the failure of France to reflect "the change of the distribution of property and wealth [that] ceased to be the prerogative of a few" (Acton, 2000: p. 1), or the 1788 drought, we shall find that facts are not at all enough: I can think of a number of droughts and food shortages in numerous principalities in the eighteenth century, non of which resulted in a revolution, as neither did the iniquitous and anachronistic socio-economic conditions of the Kingdom of the Two Sicilies in the nineteenth century. Taine's argument of the thought that permeated France has much import and cannot be discounted: unquestionably, ideas do exist and possess a truth just as facts do, much to Veyne's discomfiture.

The imposing - and slanted - theoretical structure that Murphy is elevating, is irretrievably weakened by a fatal contradicttion, which is his latest work, Truth and History, is most flagrantly evident:

History, as all historians agree [sic], is a form of empirical knowledge. Accordingly, the logic of history is similar to that of other forms of empirical knowledge. The basis of historical work is evidence, which as every philosopher of history, from Collingwood on, has agreed, consists of observations made on artifacts from the past. [...] It follows that the historian's basic task is the finding and the interpretation of such artifacts. (Murphy, 2009: p. 177)

Interpretation? Is Murphy stretching his hand to hermeneutics? Again, as with Veyne, the empirically-leaning historian is faced with the irreconcilable, logical disjunction of being both an empiricist and a hermeneutist - a hopeless desire. Murphy also manifests a serious epistemological inconsistency when at first he states, "as an empiricist, I do not believe there is any way of knowing reality except through the theory that best explains our data, and I see nothing to be gained by the belief in an unknowable metaphysical entity." (Murphy, 2009: p. 12) But only a page later, Murphy takes umbrage with Bas van Fraassen, whom he considers too severe an empiricist, due to his intransigence, ${ }^{13}$ which he considers it to be "an extreme form of empiricism that denies reality to anything not directly observable by us with our unaided senses." (Murphy, 2009: p. 14) But empiricism is severe in that it must obey rigorous rules and it does not allow unobservable data to be admitted for theoretical purposes. It need be so: if we were to betray its framework-Method-our entire scientific knowledge would collapse.

Let me address Murphy's statement that "History, as all historians agree, is a form of empirical knowledge". Can empiricism, explanation, causality, and all these conceptual ingredients of the scientifically minded, yield statements of such profundity as the following by Johann Huizinga?

The great divide in the perception of the beauty of life comes much more between the Renaissance and the modern period than between the Middle Ages and the Renaissance. The turnabout occurs at the point where art and life

\footnotetext{
${ }^{12}$ Veyne misrepresents his interpretation of Foucault in a number of ways. For a closer look at Veyne's flawed interpretation of Foucault, see Franchetti, 2011.

${ }^{13}$ See Fraassen, 1980.
} 


\section{FRANCHETTI}

begin to diverge. It is the point where art begins to be no longer in the midst of life, as a noble part of the joy of life itself, but outside of life as something to be highly venerated, as something to turn to in moments of edification or rest. The old dualism separating God and the world has thus returned in another form, that of the separation of art and life. Now a line has been drawn right through the enjoyments offered by life. Henceforth they are separated into two halves - one lower, one higher. For medieval man they were all sinful without exception; now they are all considered permissible, but their ethical evaluation differs according to their greater or lesser degree of spirituality.

[...] For the medieval man enjoyment per se is sinful. The Renaissance had managed to free itself from the rejection of all the joy of life as something sinful, but had not yet found a new way of separating the higher and lower enjoyments of life; the Renaissance wanted an unencumbered enjoyment of all of life. The new distinction is the compromise between the Renaissance and Puritanism that is at the base of modern spiritual attitudes. It amounted to a mutual capitulation in which one side insisted on saving beauty while the other insisted on the condemnation of sin [...] Only after the Puritan worldview lost its intensity did the Renaissance receptiveness to all the joys of life gain ground again; perhaps even more ground than before, because beginning the eighteenth century there is a tendency to regard the natural per se as an element of the ethically good. Anyone attempting to draw the dividing line between the higher and lower enjoyments of life according to the dictates of ethical consciousness would no longer separate art from sensuous enjoyment, the enjoyment of nature from the cult of the body, the elevated from the natural, but would only separate egotism, lies, and vanity from purity. (Huizinga, 1996: pp. 40-41)

Can logical induction yield insights into human nature such as this by Fernand Braudel?

Pius V was indeed one of these "upstarts", not a "princely" pope, not a man familiar with the ways of the world and prepared to make those compromises without which 'the world' would not go round. He had the passion, rigour and intransigence of the poor. (Braudel, 1995: p. 1027)

These excerpts whose breadth reveal a singular comprehension of the past and of the human spirit is not based on mere particulars: it is an understanding that springs from the profound knowledge of a period's facts inspirited with the impulse of universality and a deep understanding of a specific culture, which undoubtedly includes particulars, but goes beyond them. (Reading the work of such historians reveals Collingwood's notion that history is really the history of thought applied to history as bracing.) These remarkable excerpts come from historical masterworks of the twentieth century; both works are still source of admiration - and discussion. Is it possible that a Nominalist outlook by itself power such statements? Could the rejection of universals ever produce such singularly penetrating insights? I do not think so. A view that sees no strict identities reaching across different tokens-particulars - as the sole source of knowledge could never achieve what a Huzinga or a Braudel has. Surely, I am obviously not concerned with resolving the dispute-it never shall be-over whether history is a form of knowledge that is attained through Method, or whether its knowledge is hermeneutic, different and autonomous from science, and thus belonging to the field of the humanities, but, I am concerned about arguing against Nominalism's inadequacy, whatever persuasion a historian may hold about the nature of the knowledge of history.

Murphy is a potent thinker, but he is trapped by an epistemology "that is an empirical discipline located within science, rather than an a priori discipline prior to science" (Murphy, 1994 , p. xii) ${ }^{14}$ and as such, he has an ax to grind, the ax of empiricism - a most encumbering ax - and after reading his lucid but overwrought ruminations one parts from his books feeling that the ideologue has exerted himself far too much to wield this ax, which may just be too grueling for history.

The reason for a number of philosophers of history's case for Nominalism - and there are a number of them-is, I think, the fear of the specter of arbitrariness. And so, to avoid being labeled relativistic, the insecure historian legitimizes his methodology behind a gray scientism. I hope this essay be a warning to lesser historians who are not a Veyne, and do not possess his capability of immersing himself in a period's specificityregardless of the way he says one must go about it-and take refuge in a clerical empiricism which shears all beauty, effect, and meaning to their writing: the rejection of anything universal is the death of anything really historical, because it circumvents the human element - through time, of course - the paramount object of the historian's gaze.

Let us examine more closely the claim that predictive laws and the generalizations they allow, be they causal or non-causal, are functional or indeed even possible in history. I wish to look at this more closely, because so much literature has been devoted to devise some kind of lawfulness in history. In a recent article in History and Theory, Bert Leuridan and Anton Froeyman argue for the use of general laws in historiography without the more extreme leanings of a Hempel or a Murphy: in no place do they claim history to be an empirical science. However, they insist that "laws in history can be made [...] clear and fruitful" (Leuridan; Froeyman, 2012: p. 182) by applying "pragmatic laws", a "milder" form of lawfulness developed by Sandra Mitchell, which essentially holds that "evaluation is context-dependent" (Leuridan; Froeyman, 2012: p. 177) and thus "scientific generalizations $[\ldots]$ will seldom be completely universal [...]; the important question is how and to what extent they are contingent. This means that if we want to use a generalization, we need to assess the stability of these conditions. [...] Stability is a very important parameter for the evaluation of a generalization's usefulness." (Leuridan; Froeyman, 2012: p. 177) Through this context-dependent view Leuridan and Froeyman believe a scientific generalization resembling a law is believed to be possible in history.

This argument is astute but it suffers from an ontological fallacy - as we've seen repeatedly, that of using scientific practices to define, delineate, and delimit historical apprehension. These stilted and somewhat artificial efforts are again the result of the fear of relativism, as if without some scientifically postured grounding history would cease to be a sound form of knowledge, like the natural sciences. These strained efforts seem to me unnecessary. The sibylline pretensions of causality in history are the result of a confusion about the epistemology of history, which in my view is hermeneutics and not scientific

\footnotetext{
${ }^{14}$ Murphy follows Quine's view of epistemology and plainly states so.
} 
method. If historiographers and philosophers of history did not have misconceptions about historical knowledge, or if they did not harbor any uncertainty of any other form of truth that is not scientific, it seems to me that they would not keep spearheading historical theory down a spurious path; and a lot of intellectual energy would not be dissipated.

It is perhaps for this reason, too, that footnotes became such an essential part of historical writing in modern times; as Anthony Grafton admirably put it, "footnotes are the outward and visible signs of this kind of history's inward grace - the grace infused into history when it was transformed from an eloquent narrative into a critical discipline." (Grafton, 1997: p. 24) In other words, footnotes are the underpinning of a discipline that its practitioners and theorists are often fearful could drift into mendacious waters. Grafton explains that the origin of history's uncertainty was, in fact, "the vogue for Cartesian philosophy and experimental science. That, in turn, explains why Bayle felt it necessary to argue, at length, against the fashionable view that mathematics had an advantage over historical knowledge, in that 'it leads to truths not susceptible to doubt'." (Grafton, 1997: p. 208) We ought to keep in mind that a number of thinkers, of no less caliber than a Pascal, a Liebnitz, a Spinoza, a Bayle, a Vico all reacted against this constricting view of knowledge and argued "that those pure mathematicians and physicists, who are ignorant of and despise all other forms of knowledge, are wrong" (Grafton, 1997: p. 210) ${ }^{15}$ and that "certitudes of history, though different from those of mathematics, were far more concrete, more applicable to human life, and even more certain in a metaphysical sense than the profound abstractions of mathematics." (Grafton, 1997: p. 208) 16 $^{16}$

That it was an illustrious scientist, who in modern times peremptorily contrasted between the two forms of knowledge we have been discussing is ironic: in a lecture given at the commencement of the academic year at the University of Heidelberg in 1862, Herman von Helmholtz made the historic distinction between the natural sciences and the human sciences, declaring the latter to be of superior and humane significance.

It is not easy for a scientific man to convey to the scholar or a jurist a clear idea of a complicated process of nature; he must demand of them a great power of abstraction from the phenomena, as well as a certain skill in the use of geometrical and mechanical conceptions, in which it is difficult for them to follow him. On the other hand an artist will perhaps find the natural philosopher too much inclined to mechanical and material explanations, which seem to him commonplace, and chilling as his feeling and enthusiasm. Nor will the scholar or the historian, who have some common ground with the theologian or the jurist, fare better with the natural philosopher. They will find him shockingly indifferent to literary treasures, perhaps even more indifferent than he ought to be to the history of his own science. In short, there is no denying that, while the moral sciences deal directly with the nearest and dearest interests of the human mind, and with the institutions it has brought into being, the natural sciences are concerned with dead, indifferent matter, obviously indispensable for the sake of its practical utility, but apparently without any immediate bearing on the cultivation of the

\footnotetext{
${ }^{15}$ The quote is from Spinoza.

${ }^{16}$ The quote is from Bayle.
}

intellect. (Helmholtz, 1873: p. 9)

Helmholtz also argued against employing natural sciences' epistemological parameters - what he called "logical induction"-in the human sciences:

We might possibly, in opposition to logical induction which reduces a question to clearly-defined universal propositions, call the moral science's kind of reasoning aesthetic induction, because it is most conspicuous in the higher class of works of art. It is an essential part of an artist's talent to reproduce by words, by form, by colour, or by music, the external indications of a character or a state of mind, and by a kind of instinctive intuition, uncontrolled by any definable rule, to seize the necessary steps which we pass from one mood to another. If we do find that the artist has consciously worked after general rules and abstractions, we think his work poor and commonplace, and cease to admire. On the contrary, the works of great artists bring before us characters with such a lifelikeness, with such a wealth of individual traits and such an overwhelming conviction of truth, that they almost seem to be more real than the reality itself, because all disturbing influences are eliminated. (Helmholtz, 1873: p. 16)

Finally, Helmholtz made an unequivocal statement about "aesthetic induction": "This latter kind of induction, which can never be perfectly assimilated to forms of logical reasoning, nor pressed so far as to establish universal laws, plays a most important part in human life." (Helmholtz, 1873: p. 15) That a man who was first and foremost a scientist, a physicist of no less caliber than the teacher of Max Plank, the pioneer of Quantum Physics, wrote such resounding words emphasizing the humanities' superior importance is a lesson to all of us, especially to those who doubt the truth that the humanities reveal. But Helmholtz was a man of immense breadth of vision and is a figure in a class of his own who transcended the boundaries of science and art. ${ }^{17}$

If we compare Helmholtz's idea that "logical induction" is not applicable to human sciences with Veyne's theory of "retrodiction", Helmholtz's superior footing from which he is looking at the humanities is evident: Veyne wrote that, "[h]istorical synthesis is nothing but this operation of filling in; we shall call it 'retrodiction', borrowing the word from the theory of incomeplete knowledge that is the theory of probabilities. [...] So all 'retrodiction' calls into play a causal explanation and perhaps even a true law. To study historical synthesis, or 'retrodiction', is to study the part played in history by induction and in what 'historical causality' consists." (Veyne, 1984: pp. 144-145) Once again, these statements are spurred from the view that "logical induction" yields a superior form of knowledge to that of "aesthetic induction". But Helmholtz annulled this fallacy. If Veyne had been acquainted with the modern German school of

\footnotetext{
${ }^{17}$ In addition to the countless and fundamental contributions to sciencethe law of conservation of energy, the electromagnetic equation, the invention of the acoustics resonator, the invention of the ophthalmoscope, and much more-Helmholtz laid out ideas, which were later developed by Freud that were indispensible for his forming of the concept of the unconscious. Furthermore, this authentic polymath developed the "Helmholtz resonator", which was able to identify the pitch and the frequency of any sound; this machine as well as the book he wrote called On the Sensations of Tone as a Physiological Basis for the Theory of Music influenced musicologists up until the twentieth century.
} 
hermeneutics, which was commenced by Schleiermacher in the early nineteenth century and culminated with Gadamer ${ }^{18}$ in the late twentieth, who knows what interesting flowering of ideas for historiography would have flourished from his pen!

\section{A Broader Concept of Universals}

I wish to show that universals are not an incongruity in history - and neither in science - if we look at them from a wider perspective.

I cannot understand these other ingenious theories of causation. If someone tells me that the reason why a given object is beautiful is that it has a gorgeous color or shape or any such attribute, I disregard all these explanations-I find them all confusing - and I cling simply and straightforwardly and no doubt foolishly to the explanation that the one thing that makes that object beautiful is the presence in it or association with it, in whatever way the relation comes about, of absolute beauty. I do not go so far as to insist upon the precise details - only upon the fact that it is by beauty that beautiful things are beautiful. (Plato, 1961: pp. 81-82)

In this excerpt from Phaedo, Plato postulates that universals are capable of acting upon particulars ("it is by beauty that beautiful things are beautiful"): "In Phaedo, Plato endowed his Forms with causal power. They act upon particulars, giving the latter their nature, to the extent that they have a nature." (Armstrong, 1978: Vol. 1, p. 128) Armstrong's just observation brings him to theorize that universals and particulars may be conciliated even in empirical sciences, "since universals match up with the fundamental particles that science tells us about." (Armstrong, 1989: p. 88) That should settle the case for the importance of universals in history with those, like Veyne, who tirelessly advocate for Nominalism for conceiving history. Furthermore, Armstrong rightly notes that "particulars have properties that stand in relations" (Armstrong, 1978: Vol. 2, p. 133) thus echoing Plato's Parmenides, "I see nothing strange in [...] a proof that all things are one by having a share in unity and at the same time many by sharing in plurality." (Plato, 1961: p. 923) Throughout his two volumes, Armstrong's thorough discussion of Nominalism and Realism has the aim of accounting for universals' existence as well as their having a role compatible with empiricism; by having shown that universals themselves possess properties and relations, which constitute laws of nature, ${ }^{19}$ he revoked the incompatibility of universals with empirical knowledge.

That is a tonic against the most skeptical philosophical thinkers, and, for what concerns us, the skeptical historiographers whom we have been examining.

So if an ideal is responsible for a manifestation of a particular, how would that manifest itself in practice - in conceiving history? For example, the idea of a unified Christian Empire existed from Charlemagne to Charles V; but in $800 \mathrm{AD}$ what was achieved was very different from what the empire came to be under emperor Frederick II; and that, too, was different during Charles V's rule. Frances Yates, for example, pointed out that Charles' abdication in 1555 was an implicit realization that

\footnotetext{
${ }^{18}$ For a discussion of the progression of hermeneutics' gradual appropriation of its foundational role in history, see Franchetti, 2013.

${ }^{19}$ See Armstrong, 1978: Vol. 2, p. 4
}

the figure of an emperor under whom a unified Christianity could exist was anachronistic: the ideal of a Christian Empire had vanished. ${ }^{20}$ In fact, the only real case for the existence of a Christian empire may be made for the fourth century AD, as André Piganiol persuasively outlined in his L'Empire Chrétien. ${ }^{21}$ According to him, for seventy years, from 325 - the year of the Council of Nicaea, the first ecumenical council of the Church (promoted by Constantine the Great), in which the Trinity, the relationship between God the Father and The Son, the drafting of the Credo Niceum, as well as other fundaments of doctrinal orthodoxy where settled - to 395-when Theodosius, the last emperor to rule over both halves of the Christianized Roman Empire died and the empire splintered forever in East and West, with the latter soon disintegrating with the Goth invasions - according to Piganiol a unified, Christian empire did exist. The perspective of such works, so rich in historical comprehension, is certainly the consequence of a regard for universals as well as particulars. And that seems to me understanding of a vanished past of the utmost value, just like the magisterial examples of Huizinga and Braudel.

With this concept of "powered" universals, even Gauchet's justification for Nominalism can be criticized. If history is the study of change of human practices through time, and if, as Gauchet suggests, we understand historical events or practice merely as particulars, and thus Nominalism is "the only position that can adequately open him to the inexplicable singularities of a process of permanent innovation", how are we to compare these singularities with another, if we do not see particulars as standing in relations? Would it be possible to set, using our example above, the Council of Nicaea in relation to the idea of empire? How could we make historical conclusions, if not against the necessary, immovable fixity of the universal which the particular we are examining is a set of? And even in the differentiation of particulars themselves - a fundamental task of the historian, as we've seen in the examples of "the State" in different epochs-how can one do so without universals? "Lacking universals, a Nominalist cannot relate them! So he is nailed to the Humean or the Singularist cross." (Armstrong, 1978: Vol. 2, p. 151)

Dilthey spoke most convincingly of the relationship, and consequently of the existence of universals when he wrote that, "The individual always experiences, thinks, and acts in a sphere of commonality, and only in such a sphere does he understand. Everything that has been understood carries, as it were, the mark of familiarity derived from such common features. We live in this atmosphere; it surrounds us constantly; [...] we ourselves are woven into this common sphere. This results in a reciprocal dependence the way we apprehend each particular of the human sciences within the communal, historical whole of which it is a part $[\ldots]$ In the progress of the human sciences, [...] we apprehend the human world around us [from] the reciprocal dependence of universal and singular knowledge." (Dilthey, 2002: pp. 168, 174)

\section{Conclusion}

In closing this essay I wish to sum up briefly the conclusions we can draw about Nominalism in history, and, as a result of my discussion, offer a view of history that may settle the

\footnotetext{
${ }^{20}$ See Yates, 1975: pp. 20-28.

${ }^{21}$ See Piganiol, 1947.
} 
"stormy grounds" of historiography.

Particulars, we have seen, are fundamental for the historian to decipher, discern, and distinguish the period or the event he is scrutinizing; but, the consciousness of universals, too, is essential for the apprehension of any human occurrence. Nominalism or Nominalistic stances are upheld in historiography due to the disquieting but false pretense that accepting universals will induce haziness to the historian's gaze: it is time that historians lose this fear, for the historian recreates a tapestry of the past through many "a 'track', as it were- the mark, perceptible to the senses, which some phenomenon, in itself inaccessible, has left behind." (Bloch, 1953: p. 55) And so, both particulars and universals are essential for us to make sense of the world - even more so for historians who have to make sense of a world that no longer exists except in traces of it. Armstrong stated it perfectly when he said that, "[ $\mathrm{t}]$ he conclusion drawn is that particularity and universality, irreducible to each other, are both involved in all existence." (Armstrong, 1978: Vol. 1, p. xiv) This statement relates just as well to history.

Therefore particulars are absolutely indispensable, but the rejection of universals, Nominalism, is absolutely dispensable. Especially if we accept Armstrong's wider view of universals that I have presented above, which makes universals reconcileable with empiricism. And that buries Nominalism for a Veyne-who not only stresses empiricism in historical apprehension, but also openly reject universals - but also for a Foucault and a Murphy, whom we have seen fixed on a view of history as an empirical discipline.

As to the status of history as an empirical discipline, we have seen that even if we were to accept the foolish idea that history is nothing but empirical knowledge, universals still could not be discounted. I hope to have shown to some extent that Nominalism in history is a misconstrual of the historian's methodology, since, though essential, the scrutiny of particulars cannot occur without the awareness of universals. The historian must therefore harmonize both an empirical stance-especially when sources from the past are faced-and hermeneutical understanding. It is for this reason that history is an enormously difficult discipline, which Macaulay justly acknowledged to have but few masters; and it is for this reason that we historians must constantly be able to shift our thought from a macro to a micro degree of understanding; historical knowledge is just that.

It is true that history is indeed a form of factual knowledge, but since it pertains to occurrences in the past that cannot be tested, it cannot be considered a purely empirical discipline; yet, of course, there is factual evidence that forbids statements such as, "Louis XIV waged war against China in the tenth century". That satisfies one of history's offices - that of making accurate, discernible statements about the past. But obviously history has - justly - much wider contentions. Where the latter lie, interpretation enters the historian's arsenal. And it is here that we are faced with a crux, which has cast an endless conceptual problem of history's nature: Murphy has justly stated that, "it is fair to say that the philosophy of history is currently something of a mess." (Murphy, 1994: p. x) This "mess" is principally due to the difficulty for minds grounded in an age which accepts scientific facts as the only source of truth to bridge the gap between Method and hermeneutics. ${ }^{22}$ I think it is precisely here that the fulcrum of the problem - and the solution — of the philosophy of history lies.

\footnotetext{
${ }^{22}$ Here lies Gadamer's invaluable contribution to our field: the persevering and patient elucidation that hermeneutics is a practice and not a method.
}

Salient examples are the texts we have examined: Veyne and Murphy all proclaim in their introductions that "history is not a science", but in their discussion of "historical truth" they cannot hold back from Nominalism or logical formulae with lots of P's and Q's. This rather clearly shows that these historiographers have not bridged the gap between Method and hermeneutics, our discipline's most equivocal aspect, which Anthony Grafton so rightly defined as "that strange hybrid of science and art." (Grafton, 1997: p. 235)

So why are so many theoreticians so attached to a Nominalist position? As I have already noted, I think it is because in their eyes the specter of arbitrariness is raised every time we make a statement that employs universals, for it seems to them that calling upon universals leads down the relativistic path.

"The generations just prior to our own, in the last decades of the nineteenth century and even in the first years of the twentieth, were as if mesmerized by the Comtian conception of physical science. This hypnotic schema, extending to every province of the intellect, seemed to them to prove that no authentic discipline could exist which did not lead, by immediate and irrefutable demonstrations, to the formulation of absolute certainties in the form of sovereign and universal laws." (Bloch, 1953: p. 14)

I believe along with Bloch and many others, that there is no need to apply scientism to history for fear of not being taken seriously; I have read endless, dispiriting volumes ${ }^{23}$ that not only blindly defend Nominalism but advance even more radical and misconceived ideas of empirical strictures and law-covering models for history. The Nominalist view restricts from a complete and exhaustive understanding of history, because no matter which view one has of history, Nominalism is deficient, since it is irreconcilable from a humanistic perspective, and, from a scientific standpoint, Armstrong has convincingly noted that "where there are laws there exist universals." (Armstrong, 1978: Vol. 2, p. 151) But such attempts to apply natural sciences' systems to history imply that history is incapable of unveiling or unveiling truths opposed to scientific understanding.

$[\ldots]$ the human sciences are a long way from regarding themselves as simply inferior to the natural sciences. Instead, possessed of the intellectual heritage of German classicism, they carried forward the proud awareness that they were the true representatives of humanism. The period of German classicism had not only brought about a renewal of literature and aesthetic criticism, which overcame the outmoded baroque ideal of taste and of Enlightenment rationalism; it had also given the idea of humanity, and the ideal of enlightened reason, a fundamentally new content. More than anyone, Herder transcended the perfectionism of the Enlightenment with this new ideal of "cultivating the human" and thus prepared the ground for the growth of the historical sciences in the nineteenth century. The concept of self-formation, education, or cultivation (Bildung), which became supremely important at the time, was perhaps the greatest idea of the eighteenth century [...] (Gadamer, 2004: p. 8).

I should like to offer at this point a most compelling example of the untenability of strictly empirical views of history, which

\footnotetext{
${ }^{23}$ Mark Day's The Philosophy of History; Georg Iggers's Historiography in the Twentieth Century; What is History Now? Edited by David Carradine; to cite just a few.
} 
touches ever so closely upon history's essence itself. Say, for example, that historian $a$ has read exactly the same texts pertaining to the Renaissance as historian $b$. Their vision and understanding of that period shall inevitably differ considerably. How can a view of history as an empirical form of knowledge withstand, let alone explain any discrepancy at all? Here, in my view, lies the marrow of history's dilemma: that different accounts would spring from sources identical with each other is the ever fascinating aspect of history, for history is but the thought of different men. The very root itself of the word "history" points to this: its root "his" is the Indo-European "vid" which simply means "view", suggesting that the cardinal factor in history-making is indeed a historian's own, particular outlook.

The latter is achieved by integrating judiciously history's singular, three main elements, which are unique to it: philology, hermeneutics, narrative. These are, according to me, the critical, constitutive elements of history. The first element is the most scientific in nature. Peculiarly though, it did not have historical pretensions at first, or, as some would rightly claim, it did not propose - or expect - to inaugurate modern historiography: when Lorenzo Valla wrote his devastating On the Donation of Constantine in 1440, he did not expect that what was intended mainly as a linguistic feat aimed at proving the Vatican's forgery $^{24}$ of a document purporting the Church to be the inheritor of the Roman Empire by the hands of emperor Constantine the Great would lead to a fundamental branch of modern historiography. But it did and from a philological endeavor modern history sprung into being. ${ }^{25}$ The second, hermeneutics, is, as I have been suggesting throughout this essay, the practice through which an historian understands history and is able to articulate it. Narrative is the third element of history, which a history inevitably calls for in writing it. Despite the Annales school of history displaced for a while a strictly narrative focus-which was the cornerstone of the vast, synthetic historical works until the nineteenth century-I agree with Paul Ricoeur that "the narrativist interpretation is correct in its clear perception that the specifically historical property of history is preserved only by the ties, which continue to connect historical explanation to our narrative understanding." (Ricoeur, 1984: Vol. 1, p. 228) And even Braudel's The Mediterranean and the Mediterranean World in the Age of Philip II which is perhaps the greatest work to come out of the Annales school, as well as the most argumentative work against narrative in history, in its entirety is experienced as "a grand narrative of the retreat of the Mediterranean from general history." (Ricoeur, 1984: Vol. 1, p. 217) Yet, the narrativist claim is quickly returned in favor and does not need much defense today: through Arthur Danto, Paul Ricoeur and the postmodernist stance of Hayden White, narrative in history has been restored, though, at times, with some gross exaggerations.

If we were to acknowledge that the historian's task is to coordinate this triangulation I have outlined, I think many misunderstandings and their resulting abuses, which disorient current historiography would be avoided.

Lastly, I should like to mention Benedetto Croce, who of late is overlooked in English-speaking historiography. Croce was an authentic philosopher as well as an historian, who did not exhibit aporias in his thought; he elicited Collingwood's admiration, who said of him that "it was the clean cut which he [Croce]

\footnotetext{
${ }^{24}$ See Valla, 2007.

${ }^{25}$ See Kelley, 1970.
}

made in 1893 between the idea of history and the idea of science that enabled him to develop the conception of history so much farther than any philosopher of his generation." (Collingwood, 1946: p. 193)

Croce's argument toward an identity of history completely independent from empiricism was to unhinge it from the idea of "universal history". Universal history was an inheritance of German idealism; it was an ideal shared by the German historical school of the nineteenth century, which believed there was a history that existed in itself that was an objective act of self-consciousness part of a wider, collective consciousness. This was a manifestation of a concept that had originated in the eighteenth century with Voltaire's Essai sur les Moeurs, but which sprouted fully in Germany with Hegel's concept of Weltgeist; its effects persisted in historians' thought throughout the nineteenth century. Ranke was a paradigmatic example, for he believed history to be composed of "spiritual beings" which in their totality would constitute "world history"; Droysen sought to understand the "inner essence" of things; Dilthey conceived of the historical world as a text to be deciphered. But Croce thought that "unless there is some way of knowing the real that is independent of our data, the postulation of such an independent reality leaves us with an unknowable ding-ansich." (Croce, 1923: p. 14) Croce then spoke crucially on the "thing-in-itself" in history: "we know at every moment all the history that we need to know [...] that 'remaining' history is the eternal phantom of the 'ding-an-sich', which is neither the 'thing' nor 'in-itself', but only the imaginative projection of the infinity of our action and of our knowledge." (Croce, 1923: p. 55) This statement was Croce's way of dispelling the notion of universal history. But Croce made sure to add that "to negate universal history does not mean to negate the universal in history." (Croce, 1923: p. 59)

Nominalism - the rejection of universals - again just seems to be an unsuitable stance in any sound philosophy of history.

I do not believe that we live in a Fukuyama-like moment (at the "end of history") but I do believe that if we continue to abuse and stretch history's fabric with theoretical forcings, Marc Bloch's warning may come true:

It is not itself inconceivable that our civilization may, one day, turn away from history, and historians could do well to reflect upon this possibility. If they do not take care, there is danger that badly understood history could involve good history in its disrepute. But should we come to this, it would be at the cost of a serious rupture with our most unvarying intellectual traditions. (Bloch, 1954: p. 5)

It is our task to see that this not be so.

\section{REFERENCES}

Acton, J. E. E. (2000). Lectures on the French Revolution. Indianapolis: Liberty Fund.

Aristotle (1946). Poetics. The works of Aristotle translated into English. Vol. XI. Oxford: Clarendon Press.

Armstrong, D. M. (1978). Universals \& scientific realism. Cambridge: Cambridge University Press.

Armstrong, D. M. (1989). Universals: An opinionated introduction. London: Westview Press.

Bloch, M. (1953). The historian's craft. New York: Alfred A. Knopf.

Bloch, M. (2005). Scritti sulla storia come scienza. Rome: Centro di Ricerca.

Braudel, F. (1995). The Mediterranean and the Mediterranean World 


\section{FRANCHETTI}

in the age of Philip II. Berkley: University of Califorina Press. Collingwood, R. G. (1946). The idea of history. London: Oxford University Press.

Croce, B. (1923). History, its theory and practice. New York: Harcourt, Brace \& Co.

Dilthey, W. (2002). Selected works. Vol. 3. Princeton: Princeton UP.

Foucault, M. (1994). The order of things: An archaeology of the human sciences. New York: Vintage Press.

Franchetti, C. (2011). Did foucault revolutionize history? Open Journal of Philosophy, 1, 84-89. doi:10.4236/ojpp.2011.12014

Franchetti, C. (2013). Anticipations of Hans Georg Gadamer's epistemology of history in Benedetto Croce's philosophy of history. Open Journal of Philosophy, 3, 273-277. doi:10.4236/ojpp.2013.32043

Fraassen, B. van. (1980). The scientific image. Oxford: Clarendon Press. doi:10.1093/0198244274.001.0001

Gadamer, H. G. (2004). Truth and method. London: Continuum.

Gauchet, M. (1986). La nominalisme historien. A propos de "Foucault Revolutionne l'histoire", De Paul Veyne. Social Science Information, 25, 401-419. doi:10.1177/053901886025002005

Gooch, G. P. (1952). History and historians in the nineteenth century. London: Longmans, Green \& Company.

Grafton, A. (1997). The footnote: A curious history. Cambridge: Harvard University Press.

Helmholz, H. (1873). Popular lectures on scientific subjects. London: Longmans, Green \& Co.

Huizinga, J. (1996). The autumn of the middle ages. Chicago: University of Chicago Press.

Hume, R. J. (1999). Reconstructing contexts: The aims and principles of Archeao-historicism. Oxford: Clarendon Press. doi:10.1093/acprof:oso/9780198186328.001.0001
Kelley, D. R. (1970). Foundations of modern historical scholarship. New York: Columbia University Press.

Leuridan, B., \& Froeyman, A. (2012). On lawfulness in history and historiography. History and Theory, 51, 172-192. doi:10.1111/j.1468-2303.2012.00620.x

Murphy, M. G. (1994). Philosophical foundations of historical knowledge. Albany: State University of New York Press.

Murphy, M. G. (2009) Truth and history. Albany: State University New York Press.

Nadel, G. (1964). Philosophy of history before historicism. History and Theory, 3, 291-315. doi:10.2307/2504234

Piganiol, A. (1947). L'Empire Chrétien. Paris: Presses Universitaires de France.

Plato (1961). The collected dialogues of Plato. New York: Bollingen.

Ricoeur, P. (1984). Time and narrative. Chicago: University of Chicago Press. doi:10.7208/chicago/9780226713519.001.0001

Russell, B. (2007). A history of western philosophy. New York: Simon $\&$ Schuster, Inc.

Taine, H. (1986). Les origines de la France contemporaine: L'ancien régime. Paris: Robert Laffont.

Valla, L. (2007). On the donation of constantine. Cambridge: Harvard University Press.

Veyne, P. (1984). Writing history. Middletown: Wesleyan University Press.

Veyne, P. (1997) Foucault revolutionizes history. Foucault and his interlocutors. Chicago: University of Chicago Press.

Veyne, P. (2010). Foucault: His thought, his character. Cambridge: Polity.

Yates, F. (1975). Astraea: The imperial theme in the sixteenth century. London: Routledge \& Kegan Paul. 